The Journal of Engineering Research Vol. 5, No.1 (2008) 20-29

\title{
Biosorption of Zinc on Immobilized Green Algae: Equilibrium and Dynamics Studies
}

\author{
D. Sheikha1, I. Ashour*2 and F.A. Abu Al-Rub ${ }^{3}$ \\ ${ }^{1}$ Department of Chemical and Petroleum, UAE University, P.O. Box 17555 Al-Ain, UAE \\ ${ }^{2}$ Department of Petroleum and Chemical Engineering, Sultan Qaboos University, P.O. Box 33, Al-Khoud, \\ Muscat 123, Sultanate of Oman \\ ${ }^{3}$ Chemical Engineering Department, JUST, P.O. Box 30, Irbid, Jordan
}

Received 29 March 2006; accepted 24 January 2007

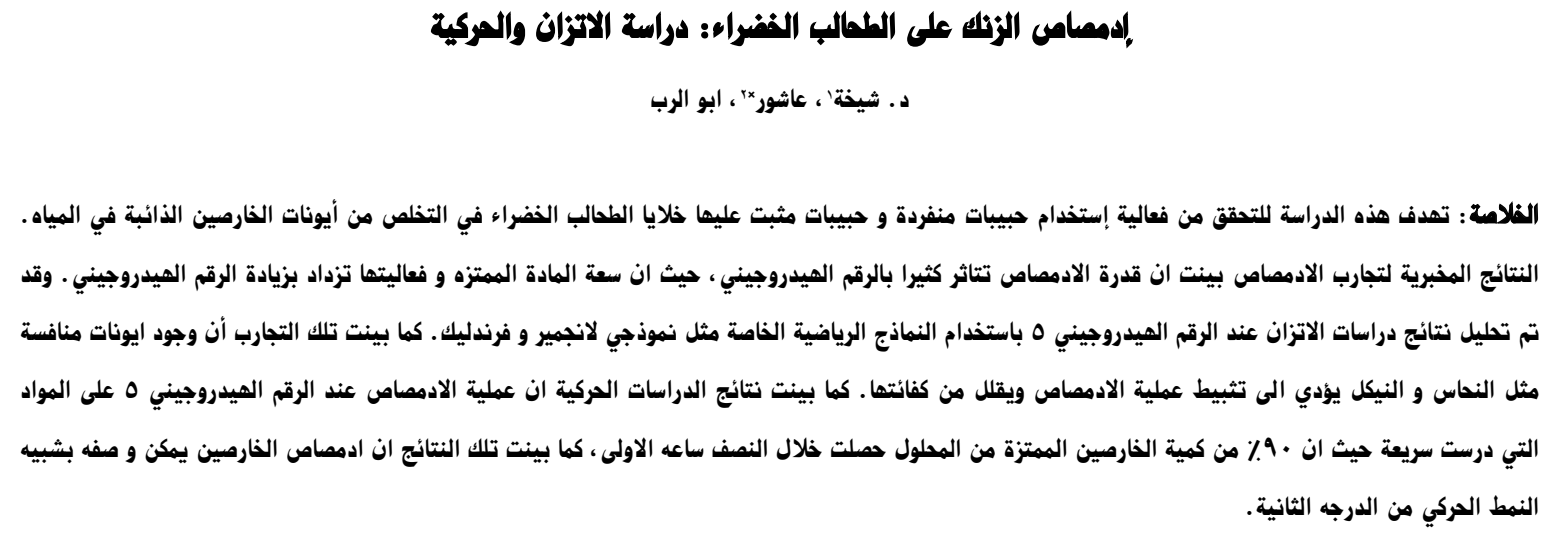

الهنرداه الهناهية: الادمصاص الحيوي ، الهعادن الثقيلة، الطحالب الخضراء الهثبتة، الالجينات، نهط الدراسة الحركية من الدرجة الثانية، الاتزان عند درجات حرارة ثابتة.

\begin{abstract}
The efficacy of using blank alginate beads and immobilized dead algal cells for the removal of zinc ions from aqueous solutions was investigated. It was found that the sorption capacities were significantly affected by solution $\mathrm{pH}$; with higher $\mathrm{pH}$ favoring higher zinc ion uptake. Dynamics and isotherm experiments were carried out at the optimal pH 5.0. Zinc uptake on either sorbent was found to be rapid where approximately $90 \%$ of the maximum zinc uptake occurred within the first $30 \mathrm{~min}$ in both cases of blank alginate and immobilized algal cells. The equilibrium data for the biosorption of zinc ions onto both sorbents were fitted to the Langmuir, Freundlich, and Dubinin-Radushkevich (D-R) isotherm equations. The presence of copper and nickel in aqueous solutions was found to suppress the sorption process. The results of the dynamics studies revealed that the biosorption of zinc on immobilized dead algal cells followed pseudo-second order kinetics with little intraparticle diffusion mechanism contribution.
\end{abstract}

Keywords: Biosorption, Heavy metals, Immobilized green algae, Pseudo second order model, Alginate, Equilibrium isotherms

\section{Introduction}

In 1978, the United States environmental protection agency (USEPA) prepared a list of 129 organic and inorganic pollutants found in wastewater that constitute serious health hazards. This list, known as the Priority Pollutants List, includes the following thirteen metals: antimony, arsenic, beryllium, cadmium, chromium, copper, lead, mercury, nickel, selenium, silver, thallium, and zinc. Unlike organic compounds, metals are non-

*Corresponding author’s e-mail: ashour@squ.edu.om biodegradable and, therefore, must be removed from wastewater. Zinc is present in the air, soil, water, and in almost all food. Zinc is naturally released into the environment, although industrial activities are mostly responsible for zinc pollution. Elevated levels of zinc may come from a variety of sources like mining and foundry activities, zinc, lead, and cadmium refining, steel production, carbon combustion, and solid waste incineration. Zinc is commonly used to coat iron and other metals for the prevention of oxidation. Various zinc salts are industrially used in wood preservatives, catalysts, photographic paper, and accelerators for rubber vulcanization, ceramics, textiles, 
fertilizers, pigments, and batteries. Water reservoirs are contaminated by the run-off from these industries. Other sources of metallic zinc traces in drinking water are water treatment processes and pick-up of metallic ions during storage/distribution. These toxic metals cause accumulative poisoning, cancer, brain damage, etc., when they are found above the tolerance levels. According to few surveys from the public health services of different countries, significant number of people has been exposed to the hazards of excess metals in the municipal water supplies (Agrawal and Pandey, 2004).

Traditional treatment methods for removing zinc from wastewater include chemical solvent extraction (Kongolo, et al. 2003; Preston and du Preez, 2000), chemical precipitation (Veeken, et al. 2003), membrane filtration (Srisuwan and Thongchai, 2002), ion exchange (Kurama and Catalsarik, 2000), and adsorption (Ramos, et al. 2002; Mohan and Singh, 2002; Peric, et al. 2000; Galiatsatou, et al. 2002). For dilute metal concentration, ion exchange, reverse osmosis and adsorption can be applied. However ion exchange and reverse osmosis have high operating cost, which makes adsorption a better alternative for heavy metals removal (Abu Al-Rub, et al. 2004 ).

One of the promising techniques for the removal of metals is the use of living or nonliving organisms and their derivatives. In general, biosorption can be defined as the passive sequestering of metal ions by metabolically inactive biomass (Volesky, 2003). Biosorbents, which are sorbents of biological origin, have proved to be good sorbents for many different pollutants. Research in the area of biosorption suggests it to be an ideal alternative for decontamination of metal containing effluents (Gupta, et al. 2000). Indeed, a wide variety of microorganisms (both living and nonviable) have been found to be capable of sequestering trace levels of metal ions from dilute aqueous solutions. The nonviable forms have been proposed as potential sorbents, since these are essentially dead materials, which require no nutrition to maintain the biomass. Problems associated with metal toxicity in living biomass and the need to provide suitable growth condition also do not arise. Early studies have shown that nonliving biomass may be even more effective than living cells in sequestering metallic elements (Sheng, et al. 2004).

Three major sources of biomass can be readily identified: (1) Waste biomass (Aksu and Yener, 2001; Aksu and Gonen 2003; Aksu and Akpinar, 2001), (2) Microorganisms (Rao and Viraraghavan, 2002; Denzili, et al. 2004; Feng and Aldrich, 2004; Arica, et al. 2004; Abu Al-Rub, et al. 2004; Pagnanelli, et al. 2001; Ibanez and Umetsu, 2004). (3) Agricultural wastes bark (Mckay, et al. 1999), sugar industry mud (Magdy and Daifullah, 1998), peat (Ho, et al. 2002), tree fern (Ho et al. 2005), olive pomace ( Pagnanelli, et al. 2003), palm tree leaves (Abu Al-Rub, 2006).

Cell immobilization is an attractive technique to fix and retain biomass on suitable natural or synthetic materials support for a range of physical and biochemical unit oper- ations (Abu Al. Rub, et al. 2004). The main advantages of this technique include: improvement of biomass performance, biosorption capacity and facilitate separation of biomass from pollutant bearing solution.

The objective of this study is to investigate the efficacy of using blank alginate beads and immobilized algal biomass for the removal of zinc ions from aqueous solutions. The effects of different parameters, such as solution $\mathrm{pH}$, shaking time, and zinc ions concentrations on the sorption capacity were investigated. Comparison between sorption on blank alginate and immobilized dead algal biomass will also be investigated. Equilibrium modeling will be carried out using the Langmuir, Freundlich, and Dubinin-Radushkevich isotherm equations.

\section{Experimental}

\subsection{Chemicals}

The stock solution of zinc used in this study was prepared using analytical reagent grade of $\mathrm{ZnSO}_{4} \cdot 7 \mathrm{H}_{2} \mathrm{O}$ (BDH, UK) in deionized water. $8.8 \mathrm{~g}$ of $\mathrm{ZnSO}_{4} .7 \mathrm{H}_{2} \mathrm{O}$ was weighed and added into $1000 \mathrm{ml}$ volumetric cylinder and completed with deinionized water, then stored.

\subsection{Preparation of Biosorbent}

Immobilized algal cells were prepared by entrapping powdered Chlorella Pyenoidosa (Watershed, USA) in an alginate matrix produced by ionic polymerization in calcium chloride solution, according to the following procedures (Abu Al Rub, et al. 2004): the powdered algal cells were suspended in a $2 \%$ sodium alginate (BDH, UK) solution kept at a temperature of $60^{\circ} \mathrm{C}$. The mixture was then dropped into a $2 \%$ calcium chloride (BDH, UK) solution using a peristaltic pump. The drops of Na-alginate solution gelled into $3.5 \pm 0.1 \mathrm{~mm}$ diameter beads upon contact with calcium chloride solution. The beads were washed well and then rinsed in deionized water and stored at $4^{\circ} \mathrm{C}$. For blank alginate beads, similar procedures were followed, but without algae.

\subsection{Determination of Functional Groups}

The functional acidic groups on the prepared algal cells were determined using Boehm's titration method (Abdulkarim and Abu Al-Rub, 2004; Strelko, et al. 2002): $1 \mathrm{~g}$ of the powdered algal cells was dispersed in $50 \mathrm{ml}$ deionized water. The suspension was mixed with $0.1 \mathrm{~N}$ solutions of sodium bicarbonate, sodium carbonate, and sodium hydroxide, and then shaken for $48 \mathrm{~h}$ at room temperature. After this time, the sample was left for $6 \mathrm{~h}$ so that particles can settle. The sample was then filtered and 10 $\mathrm{ml}$ of filtrate were titrated with $0.1 \mathrm{~N}$ volumetric $\mathrm{HCl}$ standards using a methyl red as the indicator. According to Boehm's titration method, sodium bicarbonate can neutralize carboxyl groups, sodium carbonate can neutralize carboxyl, lactones and lactols groups, and sodium hydroxide can neutralize carboxyl, lactones, lactols and phenols 
groups. Table 1 lists the different functional groups available on algal cells.

Table 1. The functional groups on the Algal cells

$\quad$ Functional Group
Carboxyl
Carboxyls, Lactones and Lactols
Carboxyls, Lactones, Lactols and
Phenols

Meq $\mathbf{H}^{+} / \mathbf{g}$ algae
0.02
0.01
0.035

\section{Procedure}

\subsection{Equilibrium Adsorption Isotherm}

All experiments were conducted by adding a specific amount of beads into $100 \mathrm{ml}$ reagent bottles containing 50 $\mathrm{ml}$ of the zinc solution. Different initial concentrations were used: for zinc (20-350 ppm). The mixtures in these bottles were agitated for 1 hour in a shaker at $25^{\circ} \mathrm{C}$. The zinc solution, then, was separated from sorbent and the concentration of zinc ions was determined using a Varian atomic absorption spectrophotometer (Spectra AA, 880).

The uptake, which represents the amount sorbate sorbed per units mass of sorbent is calculated using the following equation:

$$
Q_{e}=\frac{\left(C_{o}-C_{e}\right) V}{W}
$$

where $Q_{e}$ is the uptake $\left(\mathrm{mg} / \mathrm{g}\right.$ ) at equilibrium, $C_{o}$ the initial concentration sorbate $(\mathrm{mg} / \mathrm{ml}), C_{\mathrm{e}}$ the concentration at equilibrium $(\mathrm{mg} / \mathrm{ml}), V$ the initial volume of solutions, and $W$ is the mass of sorbent $(g)$.

\subsection{Adsorption Dynamics}

The dynamics studies were carried out by conducting batch biosorption experiments with $100 \mathrm{ppm}$ of zinc at $p H$ 5.0. Samples were taken at different time periods and analyzed for their zinc concentrations.

\subsection{Competitive Biosorption}

The competitive biosorption of zinc with nickel and copper were investigated. The studies involved experiments with different metals concentrations. All the experiments were conducted at $25^{\circ} \mathrm{C}$ using the same procedures used in the single adsorption experiments, and were carried out in triplicate.

\section{Results and Discussion}

\subsection{Effect of pH on Zinc Biosorption}

Heavy metals biosorption is highly $\mathrm{pH}$ dependent (Abu $\mathrm{Al} \mathrm{Rub}$, et al. 2004). The effect of $\mathrm{pH}$ on zinc sorption capacity of the immobilized dead algal cells was studied at $100 \mathrm{ppm}$ zinc initial concentration and $0.15 \mathrm{~g}$ of algal cell. Figures 1 and 2 demonstrate the variation of the uptake of zinc with equilibrium $\mathrm{pH}$. The uptake of zinc increases from 1.83 to $7.26 \mathrm{mg} / \mathrm{g}$ over a narrow $\mathrm{pH}$ range (3.0-5.0).

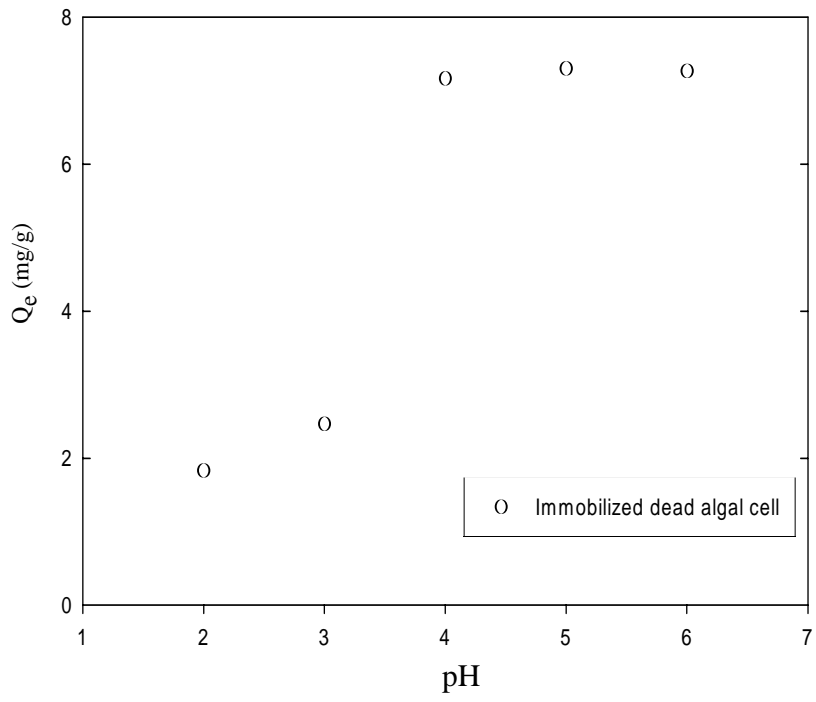

Figure 1. Effect of $p H$ on zinc uptake (initial zinc ions concentration $=100 \mathrm{ppm}$ mass of algal cell $=1.15 \mathrm{~g}$ )

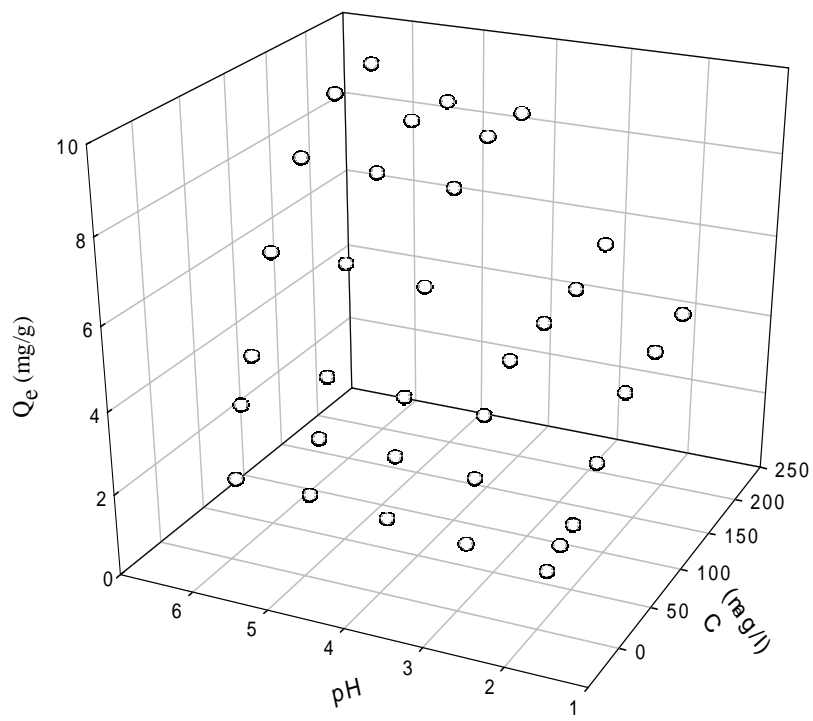

Figure 2. Effect of $p H$ on zinc removal (mass of algal cells $=0.30 \mathrm{~g}$ )

No significant increase in zinc uptake at $\mathrm{pH}$ values above 5.0 was observed. Similar trend was obtained in previous studies (Martins, et al. 2004; Mohapatra and Gupta, 2005; Ramos, et al. 2002). Solution $p H$ affects both cell surface metal binding sites and metal chemistry in water (Abu Al-Rub, et al. 2006). At low pH values, ion exchange reaction involving metals are in competition with the high concentrations of $\mathrm{H}^{+}$in the solution. With increasing $\mathrm{pH}$, more ligands, such as amino and carboxyl groups, on sorbent are exposed and thus negative charges result and attraction between these negative charges and the metals increases the biosorption capacity on the cell surface. Another reason for increasing zinc removal is that the isoelectric point for algal biomass is at $p H 3.0$ (Abu Al-Rub et al. 2006). At $p H$ values above zero-point charge, the algal cells would have a negative net charge 
and the ionic state of ligands on algal cell surface is such as to endorse reaction with zinc ions. Thus, electrostatic attraction between zinc and the negatively charged algal cells surface occurs which enhances the biosorption above pH 3.0 (Abu Al-Rub, et al. 2006).

\subsection{Dynamics of Zinc Biosorption}

The variation in uptake of zinc with shaking time was studied using solutions of zinc with initial concentration of $100 \mathrm{ppm}$ at $\mathrm{pH} 5.0$ and $0.3 \mathrm{~g}$ of algal cell. The shaking time was varied from 3 to $180 \mathrm{~min}$. Figure 3 reveals the variation of the uptake of zinc versus time for immobilized inactive algae and blank alginate. The maximum zinc uptake with either sorbent was reached after $60 \mathrm{~min}$. Figure 3 also indicates that the sorption of zinc on these sorbents involves two stages: in the first stage, sorption is rapid where approximately $90 \%$ of the maximum zinc uptake occurs within the first $30 \mathrm{~min}$ in both cases of blank alginate and immobilized algal cells. This rapid sorption indicates that passive surface sorption occurs on the algal cells or beads surface. The second stage is slow and may involve other adsorption mechanisms such as intraparticle diffusion. The advantage of such rapid sorption in practical applications is that smaller reactor volumes can be used (Abu al Rub, et al. 2004).

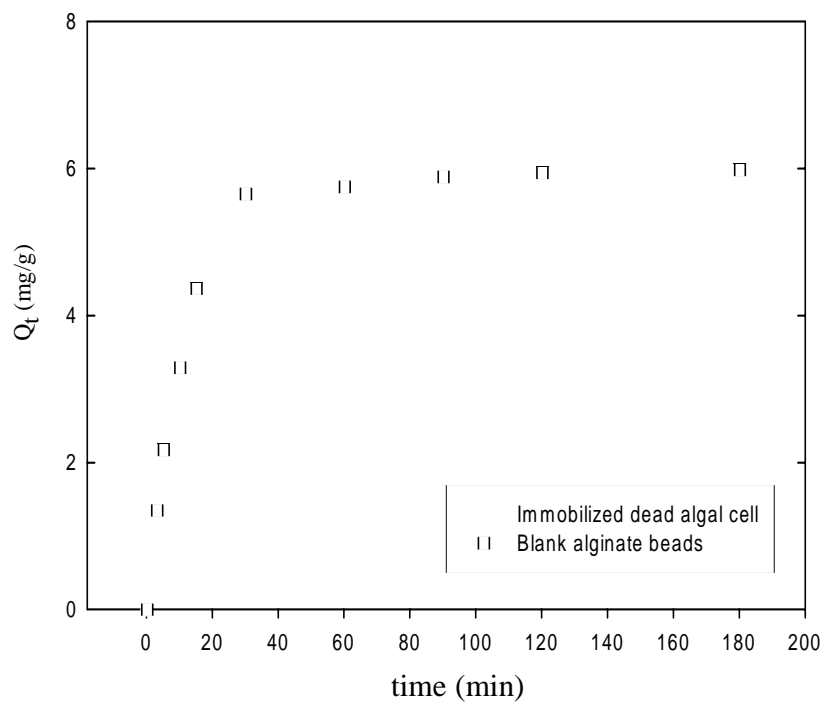

Figure 3. Effect of shaking time (initial zinc ions concentration $=100 \mathrm{ppm}, \mathrm{pH}=5.0$, mass of algal cell $=0.3 \mathrm{~g}$ )

The pseudo-second order kinetic, suggested by (Ho and McKay, 1999 and Ho, 2004), is based on the sorption capacity of the sorbent and is given by:

$$
\frac{d Q_{t}}{d t}=k\left(Q_{e}-Q_{t}\right)^{2}
$$

An integrated pseudo-second order rate law can be obtained from Eq. (2) for the boundary conditions $t=0$ to $t=t$ and $Q_{t}=0$ to $Q_{t}=Q_{t}$, and is given by:

$$
\frac{1}{\left(Q_{e}-Q_{t}\right)}=\frac{1}{Q_{e}}+k t
$$

Eq. (3) can be rearranged to obtain a linear form:

$$
\frac{t}{Q_{t}}=\frac{t}{Q_{e}}+\frac{1}{Q_{e}^{2} k}
$$

Where $Q_{e}$ is the amount of sorbate sorbed at equilibrium ( $\left.\mathrm{mg} \mathrm{g}^{-1}\right)$;); $Q_{t}$ is the amount of sorbate sorbed at time $\mathrm{t}\left(\mathrm{mg} \mathrm{g}^{-1}\right)$; and $k$ is the equilibrium rate constant of pseudo-second order sorption $\left(g \mathrm{mg}^{-1} \mathrm{~min}^{-1}\right)$. The linear form see Eq. (4) is obtained by plotting $t / Q_{t}$ versus $t$, with the slope of $1 / Q_{e}$ and intercept of $1 / k Q_{e}{ }^{2}$, as shown in Fig. 4. The values of sorption rate constant and the equilibrium uptake with the correlation coefficient are listed in Table 2. Figure 4 and the results listed in Table 2 indicate that the kinetics for the sorption of zinc on blank alginate beads and immobilized inactive algae follow pseudo-second order kinetics.

Table 2. Kinetic parameters for the biosorption of zinc ions on immobilized dead algal cells and blank alginate beads

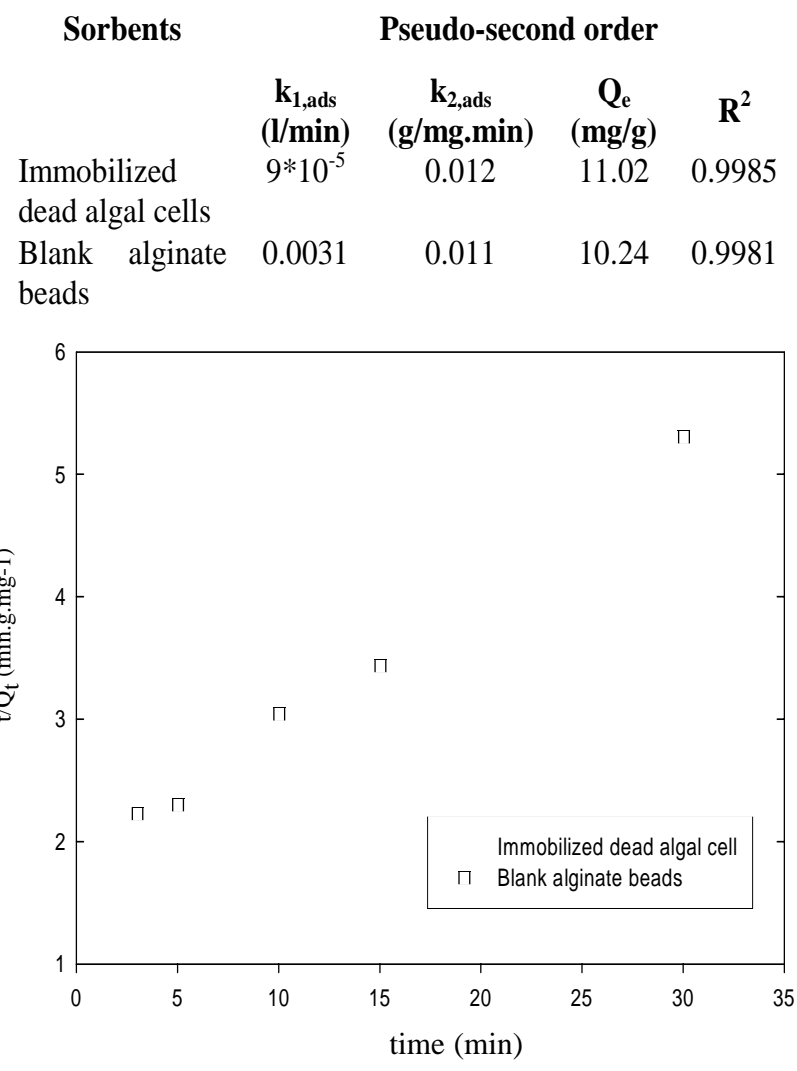

Figure 4. Kinetics of biosorption of zinc: pseudosecond order kinetics (mass of algal cell = $0.3 \mathrm{~g}$, initial zinc concentration $=100 \mathrm{ppm}$, $T=25^{\circ} \mathrm{C}, \mathrm{pH}=\mathbf{5 . 0}$ )

The Weber and Morris equation, 1963, given by Eq. (5), can be used to test for the contribution of intraparticle diffusion. 


$$
Q=k_{d} t^{0.5}
$$

where $k_{d}$ is the rate constant of intraparticle diffusion. Intraparticle diffusion mechanism would be involved if plotting $Q_{t}$ vs. $t^{0.5}$ resulted in a straight line. Figure 5 shows the variation of $Q_{t}$ versus $t^{0.5}$. For immobilized inactive algae and blank alginate beads the relationship is a straight line but doesn't pass through the origin which indicates that the intraparticle diffusion is not the only mechanism involved in the biosorption of zinc on immobilized dead algal cell.

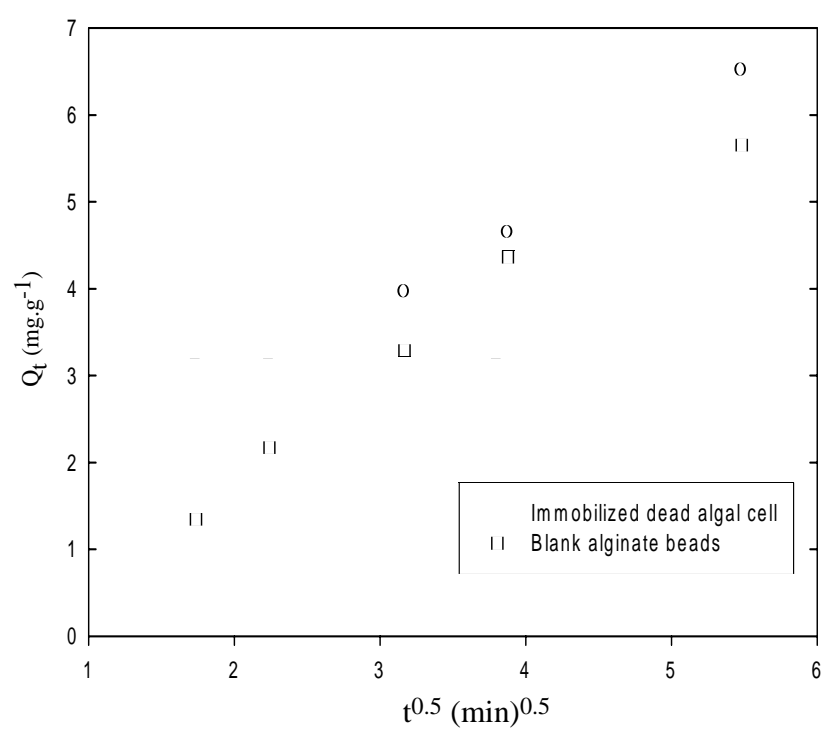

Figure 5. Variation of $Q_{t}$ versus time (Weber-Morris equation 5.6)

\subsection{Biosorption Isotherm}

Zinc ions biosorption capacities of blank alginate beads and immobilized dead algal cells are presented as a function of the equilibrium concentration of zinc ions and the results are shown in Fig. 6. Figure 6 displays that the amount of $Z^{n+2}$ ions sorbed per unit mass of the biosorbent increased with increasing equilibrium concentration of zinc ions in the biosorption medium. Higher equilibrium concentration enhances the mass transfer driving force, thus increasing the uptake. In addition, increasing equilibrium metal ion concentrations increases the number of collisions between metal ions and sorbent, which enhances the sorption process (Abu Al Rub, et al. 2004). From this Figure, the maximum biosorption capacity on the blank alginate beads was $8.58 \mathrm{mg} / \mathrm{g}$ and on immobilized dead algal cells was $9.38 \mathrm{mg} / \mathrm{g}$. Table 3 compares the maximum sorption capacities obtained in this study with some other values reported in the literature. The sorption capacity of zinc using the immobilized dead algal cells Chlorella vulgaris is greater than that has been found using similar biosorbents.

It is known that the constituents of the cells wall of algae provide an array of ligands with a mosaic of functional groups capable of binding various metallic ions.
Indeed, it has been shown that many metal-binding mechanisms are involved in the biosorption process; these include ion exchange, complexation, coordination, and microprecipitation (Sheng, et al. 2004). In addition to these, immobilization enhances the contribution of physical sorption.

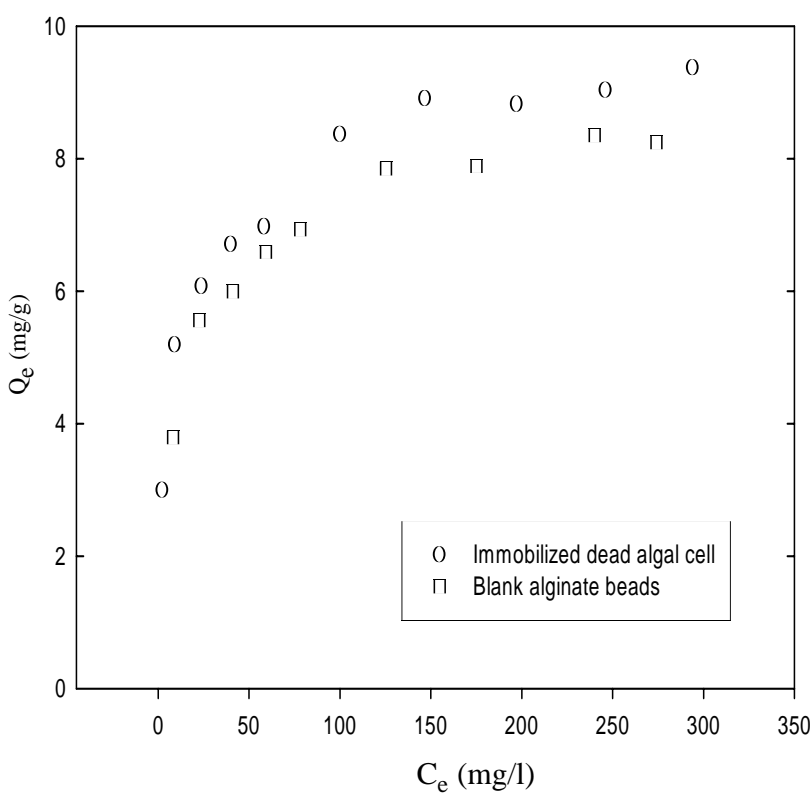

Figure 6. Experimental isotherms of zinc ions sorbed on different sorbents $(p H=5.0$ mass of algal cell $=0.3 \mathrm{~g}$ )

Table 3. Adsorption capacity for $\mathrm{Zn}^{+2}$ using different low cost adsorbents

\begin{tabular}{|c|c|c|}
\hline Adsorbent & $\begin{array}{c}\text { Adsorption } \\
\text { Capacity } \\
\text { (mg/g) } \\
\text { of } \mathbf{Z n}\end{array}$ & Reference \\
\hline aste tea leaves & 11.77 & $\begin{array}{c}\text { Tee and Khan, } \\
1988\end{array}$ \\
\hline Ioss (mixture) & 9.87 & $\begin{array}{l}\text { Al-Asheh et } \\
\text { al. } 1997\end{array}$ \\
\hline Iazelnut shells & 1.78 & $\begin{array}{l}\text { Cimino and } \\
\text { Toscano, } 2000\end{array}$ \\
\hline Peat & 9.3 & $\begin{array}{c}\text { McKay et al. } \\
1998\end{array}$ \\
\hline Fungi & 9.81 & $\begin{array}{c}\text { Puranik et al. } \\
1999\end{array}$ \\
\hline $\begin{array}{l}\text { Aquatic moss } \\
\text { Fontinalis } \\
\text { antipyretica }\end{array}$ & 15 & $\begin{array}{l}\text { Martins et al. } \\
2004\end{array}$ \\
\hline $\begin{array}{l}\text { algal cells } \\
\text { lorella vulqaris }\end{array}$ & 9.38 & This study \\
\hline
\end{tabular}

The sorption data were analyzed according to the linear form of the Langmuir isotherm

$Q=Q_{\max } \frac{b C_{e}}{1+b C_{e}}$ 
where $Q_{\max }$ is the maximum sorbate uptake under the given conditions, $b$ is a coefficient related to the affinity between the sorbent and sorbate. The plots of specific sorption $\left(C_{e} / Q_{e}\right)$ against the equilibrium concentration $\left(C_{e}\right)$ for zinc are shown in Fig. 7, and the isotherm constants $Q_{\max }, b$, along with the correlation coefficient, $R^{2}$, are presented in Table 4 . The $R^{2}$ values suggest that the Langmuir isotherm provides a good model of the sorption system. The sorption equilibrium constant of the Langmuir model $b$ provides a measure for the adsorption efficiency since it indicates the sorbent affinity at low concentrations, and hence it measures the initial gradient of the adsorption isotherm. Higher values of $b$ indicate higher affinity and thus higher sorption efficiency.

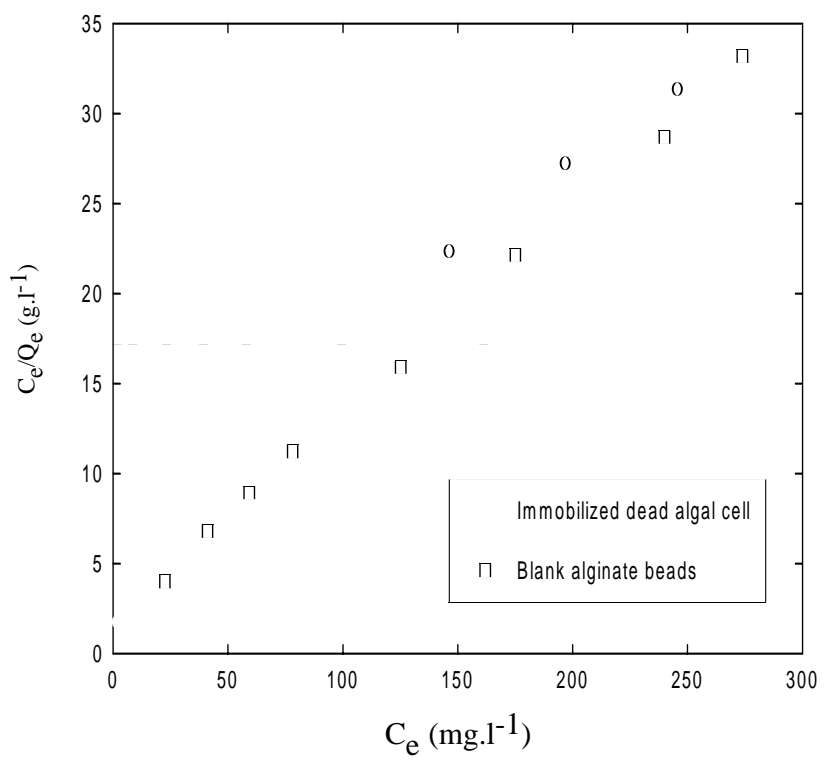

Figure 7. Langmuir isotherms of zinc ions sorbed on different sorbents of algal cell $=0.3 \mathrm{~g}, \mathrm{pH}=$ 5.0)

The Sum of the Squares of the Errors (ERRSQ) was used as a non-linear error function to determine the Langmuir parameters as used by (Ho, et al. 2002):

$$
\text { ERRSQ }=\sum_{i=1}^{p}\left(Q_{e, \exp }-Q_{e, c a l}\right)_{i}^{2}
$$

where $\mathrm{p}$ is the number of experimental data.

The results of using the non-linear error analysis are shown in Table 5, where they show that the Langmuir isotherm constants $b$, and $Q_{\max }$ are very consistent among all methods and they were very close to those obtained using linear analysis.

The Freundlich equation is one of the earliest empirical equations used to describe sorption equilibrium data. It does not establish a finite uptake capacity of the sorbent and can thus be reasonably applied in the low to intermediate concentrations ranges. The Freundlich isotherm model is given by the equation (Ho, et al. 2002):

$$
Q_{e}=K C_{e}^{1 / n}
$$

Table 4. Adsorption linear isotherms parameters for the sorption of zinc ions by blank alginate

\begin{tabular}{|c|c|c|c|}
\hline Model & Parameter & $\begin{array}{c}\text { Blank } \\
\text { alginate } \\
\text { beads }\end{array}$ & $\begin{array}{l}\text { Immobilized } \\
\text { algal cells }\end{array}$ \\
\hline \multirow[t]{3}{*}{ Freundlich } & $\begin{array}{c}K(\mathrm{l} / \mathrm{mg})^{1 / \mathrm{n}} \\
(\mathrm{mg} / \mathrm{g})\end{array}$ & 2.85 & 3.26 \\
\hline & $n$ & 5.01 & 5.15 \\
\hline & $\mathrm{R}^{2}$ & 0.95 & 0.96 \\
\hline \multirow[t]{3}{*}{ Langmuir } & $Q_{\max }(\mathrm{mg} / \mathrm{g})$ & 9.25 & 9.67 \\
\hline & $b(\mathrm{l} / \mathrm{mg})$ & 0.04 & 0.06 \\
\hline & $\mathrm{R}^{2}$ & 0.99 & 0.99 \\
\hline \multirow[t]{4}{*}{ D-R } & $Q_{\mathrm{D}}(\mathrm{mmol} / \mathrm{g})$ & 8.83 & 9.44 \\
\hline & $\begin{array}{c}B_{D} \\
\left(\mathrm{l} / \mathrm{J}^{2} \cdot \mathrm{mol}^{2}\right)\end{array}$ & $\underset{9}{2.01 * 10^{-}}$ & $2 * 10^{-9}$ \\
\hline & $E(\mathrm{~kJ} / \mathrm{mole})$ & 15.772 & 15.81 \\
\hline & $\mathrm{R}^{2}$ & 0.97 & 0.98 \\
\hline
\end{tabular}
beads and immobilized algal cells

Table 5. Adsorption non-linear isotherms parameters for the sorption of zinc ions by blank laginate beads and immobilized algal cells

$\begin{array}{lcc}\text { Model } & \begin{array}{c}\text { Blank } \\ \text { Alginate } \\ \text { Beads }\end{array} & \begin{array}{c}\text { Immobilized } \\ \text { Algal Cells }\end{array} \\ \begin{array}{l}\text { Freundlich: } K \\ (\mathrm{l} / \mathrm{mg})^{1 / \mathrm{n}}(\mathrm{mg} / \mathrm{g})\end{array} & 2.94 & 3.58 \\ \text { Freundlich } n & 5.27 & 5.86 \\ \text { Marquadt's PSD } & 0.031 & 0.12 \\ & & \\ \text { Langmuir } Q_{\max }(\mathrm{mg} / \mathrm{g}) & 8.37 & 8.83 \\ \text { Langmuir } b(\mathrm{l} / \mathrm{mg}) & 0.087 & 0.18 \\ \text { ERRSQ } & \mathbf{0 . 9 6} & 0.95\end{array}$

where $K$ and $n$ are the Freundlich constants which represent sorption capacity and sorption intensity, respectively. The linear Freundlich isotherm plots for the sorption of the zinc onto both blank alginate beads and immobilized dead algal cells are presented in Fig. 8. Table 4 shows the linear Freundlich sorption isotherm constants and the coefficients of determination; $R^{2}$. Examination of the plot and the $R^{2}$ values suggests that the Freundlich isotherm could describe the sorption of zinc on both sorbents. This is supported by the fact that algal cells have active sites with different energies, a key assumption in Freundlich isotherm model. The values of the Freundlich model parameters can be used to predict the affinity between the 
sorbate and sorbent. High values of these parameters indicate high adsorptive capacity. From Table 4 the magnitude of $K$ and $n$ for both sorbents suggests easy uptake with high sorptive capacity.

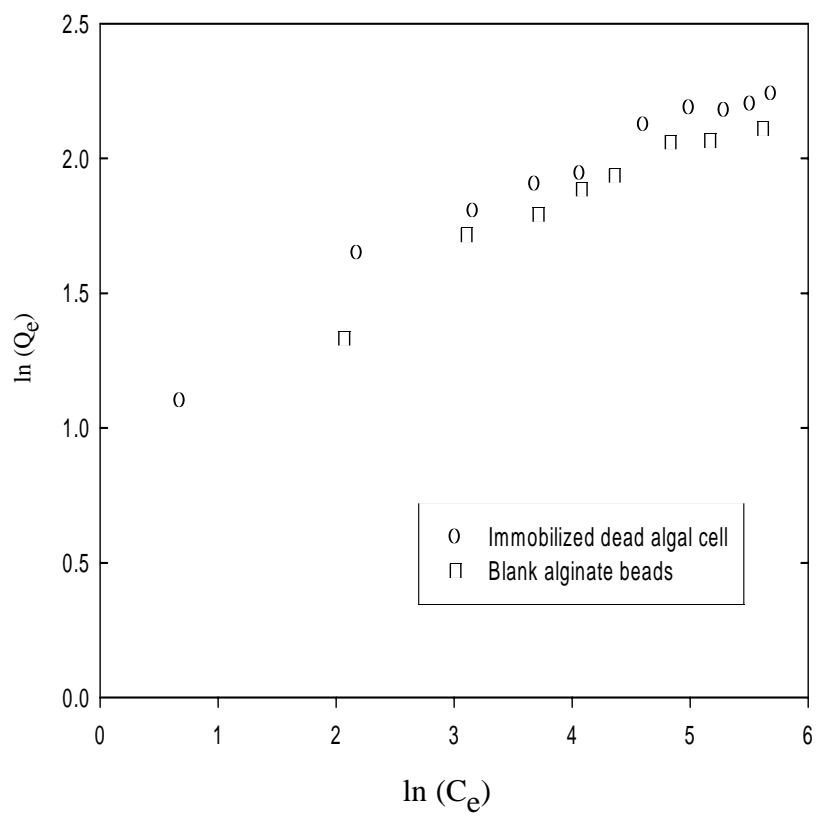

Figure 8. Freundlich isotherms of zinc ions sorbed on different sorbents (mass of algal cell $=\mathbf{0 . 3}$ $g, p H=5.0)$

The Freundlich isotherm constants were also determined by the non-linear regression of Marquardt's Percent Standard Deviation (MPSD) (Marquardt, 1963):

$$
\text { MPSD }=\sum_{i=1}^{P}\left(\frac{Q_{e, \exp }-Q_{e, c a l}}{Q_{e, \exp }}\right)_{i}^{2}
$$

and the results are tabulated in Table 5 . These results demonstrate that the values of the $K$ and $n$ obtained by non linear regression are remarkably consistent and quite similar to the linear transform values shown in Table 4.

Another less commonly used model to describe sorption of zinc on immobilized dead algal cells is the Dubinin-Radushkevich (D-R) isotherm. This isotherm is generally expressed as follows (Dubinin, 1960):

$$
Q_{e}=Q_{D} \exp \left(-B_{D}\left[R T \ln \left(1+\frac{1}{C_{e}}\right)\right]^{2}\right)
$$

Radushkevich (1949) and Dubinin (1965) have reported that the characteristic sorption curve is related to the porous structure of the sorbent. The constant, $B_{D}$, is related to the mean free energy of sorption per mole of the sorbate as it is transferred to the surface of the solid from infinite distance in the solution and this energy can be computed using the following relationship (Ho, et al. 2002):

$$
E=\frac{1}{\sqrt{2 B_{D}}}
$$

Figure 9 is a plot of the linear form of Eq. (10), and the parameters found from the slope and intercept are listed in Table 4. The values of $E$ calculated are 15.77 $\mathrm{kJ} / \mathrm{mole}$ and $15.81 \mathrm{~kJ} / \mathrm{mole}$ for blank alginate beads and immobilized dead algal, respectively. These values are within the range of ion-exchange mechanisms (8-16 $\mathrm{kJ} / \mathrm{mole}$ ) (Abu Al-Rub, 2004), confirming that the ion exchange mechanism plays a significant rule in the biosorption mechanism. This finding of the ion exchange mechanism contribution agrees with the suggested mechanism of biosorption proposed by (Volesky, 2003). The $Q_{D}$ values are consistent with the linear $Q_{\max }$ values previously determined for the Langmuir isotherm.

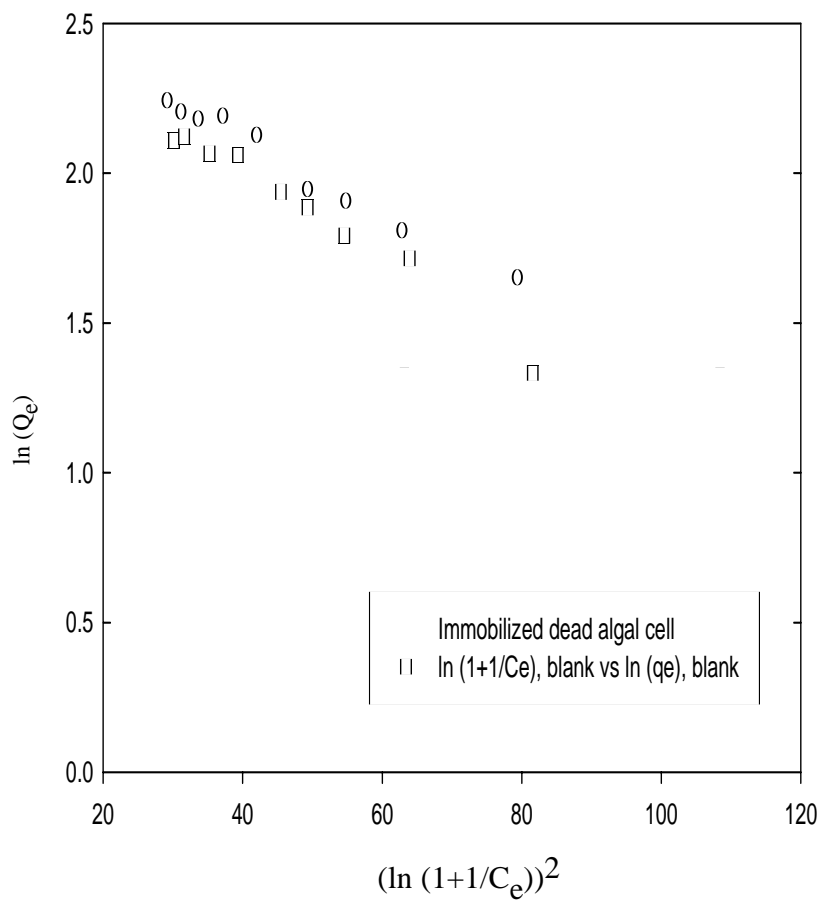

Figure 9. Dubinin-Radushkevich equation isotherm of zinc ion sorbed on different sorbents (mass of algal cell $=0.3 \mathrm{~g}, \mathrm{pH}=\mathbf{5 . 0}$ )

\subsection{Sorption/Desorption of Zinc}

Sorption and desorption of zinc on immobilized dead algal cells and blank alginate beads were investigated by conducting three repeated cycles sorption/desorption experiments. Desorption experiments were carried out by shaking the sorbents with $20 \mathrm{ml} 0.1 \mathrm{M} \mathrm{HCl}$ for two hours. The sorbents were then rinsed with deionized water to remove any residual acidity. The regenerated sorbents were then used in the removal of zinc ions and the results are demonstrated in Fig. 10. Figure 10 indicates that zinc uptake was improved after the first cycle. This improvement may be attributed to the fact that the acid used in desorption could remove some contaminants that might have been bound previously by the algal cells. 


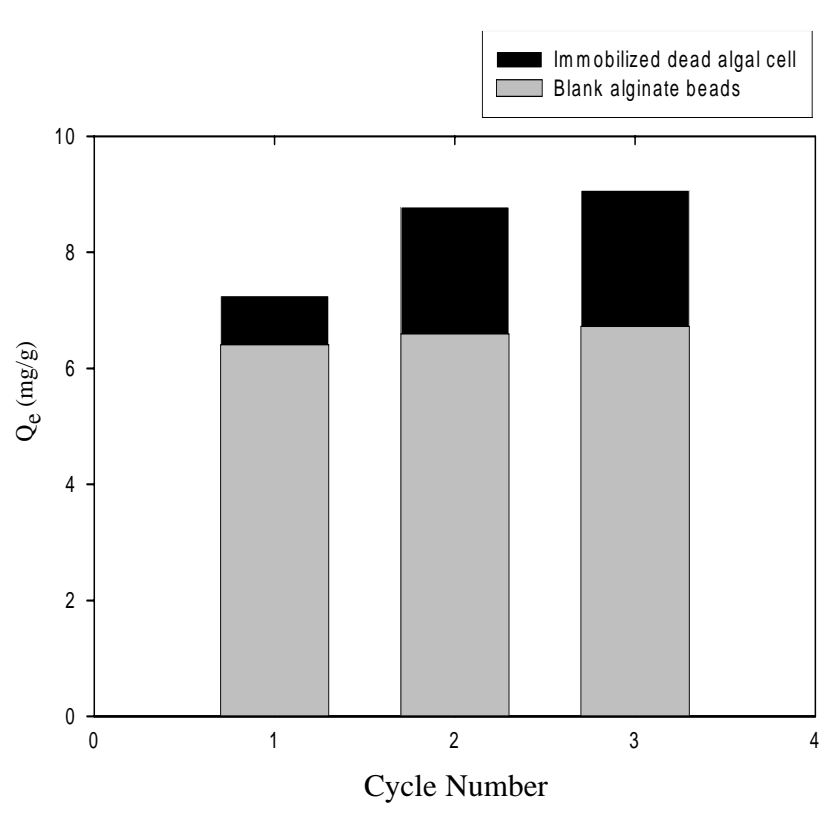

Figure 10. Repeated uptake removal of zinc (initial zinc ions concentration $=100 \mathrm{ppm}, \mathrm{pH}=$ 5.0 , mass of algal cell $=0.3 \mathrm{~g}$ )

\subsection{Effect of Impurities on Biosorption of Zinc}

The biosorption of $\mathrm{Zn}^{+2}+\mathrm{Cu}^{+2}$ and $\mathrm{Zn}^{+2}+\mathrm{Ni}^{+2}$ at equilibrium $p H 5.0$ on immobilized dead algal cells are shown in Fig. 11. These figures show the equilibrium uptake of zinc decreased regularly with increasing equilibrium metals concentrations. The decrease in the uptake of zinc in the presence of $\mathrm{Ni}^{+2}$ ions and $\mathrm{Cu}^{+2}$ ions is simple to explain. The presence of the other component develops a competition for the adsorption sites on the surface and some sites are occupied by the second component. As a consequence, the first component has a smaller "parking

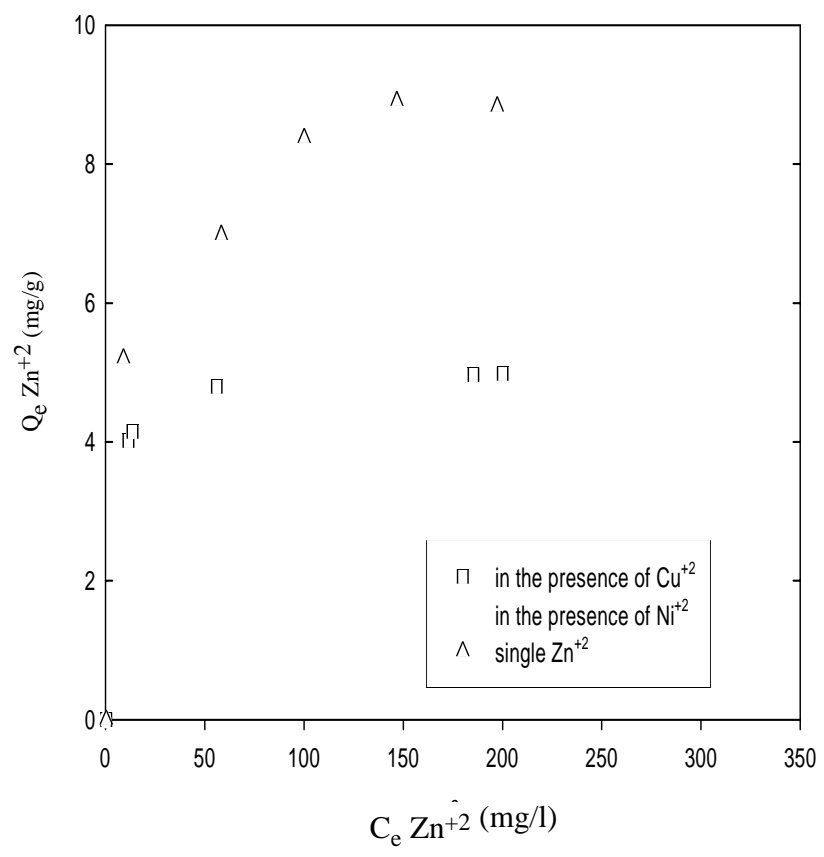

Figure 11. Effect of the presence of other metals on zinc biosorption (pH 5, mass of algal cells $=0.3 \mathrm{~g}$ ) space" and its uptake is decreased (Aksu and Akpinar, 2001). These results were in agreement with other studies using different adsorbent and/or different heavy metals (Abu Al Rub, 2004; Juang, et al. 1999).

The electronegativity values of $\mathrm{Zn}^{+2}, \mathrm{Cu}^{+2}$, and $\mathrm{Ni}^{+2}$ metal ions are $1.65,1.75$, and 1.8 respectively. The more electronegative metal ions will be more strongly attracted to the immobilized dead algal cells surface (Arica, et al. 2004). $\mathrm{Cu}^{+2}$ has the highest affinity for immobilized dead algal sites and it has a greater negativity than both $\mathrm{Zn}^{+2}$ and $\mathrm{Ni}^{+2}$. This can explain the significant suppression of $\mathrm{Zn}^{+2}$ uptake in the presence of $\mathrm{Cu}^{+2}$.

\section{Conclusions}

This study proved the practical feasibility of using blank alginate beads and immobilized dead algal cells for the removal of zinc from wastewaters. The solution $\mathrm{pH}$ plays a very important role for zinc adsorption onto both sorbents. At $p H<2$, zinc did not adsorb, the adsorption increased drastically as the $\mathrm{pH}$ was increased from 2.0 to 6.0 , and the maximum adsorption uptake was achieved at $p H$ 5.0. In addition, the uptake of zinc increased as the equilibrium zinc ion concentration increased. Sorption of zinc on these sorbents was found to follow pseudo-second order kinetics. Moreover, alginate beads and immobilized Chlorella vulgaris cells could be used in successive sorption/desorption cycles to remove zinc ions from aqueous solutions, which suggest that immobilization can provide an efficient and convenient method for repetitive use of algal cells. Sorption of zinc on alginate beads and immobilized Chlorella vulgaris has been found to follow Langmuir, Freundlich, or D-R isotherm models. The presence of $\mathrm{Cu}^{+2}$ and $\mathrm{Ni}^{+2}$ in the system led to a decrease in the removal of zinc ions by immobilized dead algal cells.

\section{Acknowledgments}

The contribution of Dr. Aly Dowdair in the analysis procedures is gratefully acknowledged.

\section{References}

Abdulkarim, M. and Abu Al-Rub, F., 2004, "Adsorption of Lead Ions from Aqueous Solutions on Activated Carbon and Chemically Modified Activated Carbon Prepared from Date Pits," Adsorption Science and Technology, Vol. 22 pp. 119-134.

Abu Al-Rub, F. A., 2006, "The Biosorption of Zinc on Palm Tree Leaves: Equilibrium, Kinetics, and Thermodynamics Studies," Sep. Sci. Technol., Vol. 41, pp. 3499-3515.

Abu Al-Rub, F. A., 2004, "Adsorption of Lead on Jordanian Low-Grade Phosphate," Ads. Sci. Technol., Vol. 22, pp. 65-179.

Abu Al-Rub, F., El-Naas, M., Benyahia F. and Ashour, I., 2004, "Biosorption of Nickel on Blank Alginate Beads, Free and Immobilized Algal Cells," Process Biochemistry, Vol. 39, pp. 1767-1773. 
Abu Al-Rub, F., El-Naas, M., Ashour, I. and Al-Marzouqi, M., 2006, "Biosorption of Copper on Chlorella Vulgaris from Single, Binary and Ternary Metal Aqueous Solutions," Process Biochemistry, Vol. 41, pp. 457-464.

Agrawal, A., Sahu, K.K. and Pandey, B.D., 2004, "Removal of Zinc from Aqueous Solutions Using Sea Nodule Residue," Physicochem. Eng. Aspects, Vol. 237, pp. 133-140.

Aksu, Z. and Akpinar, D., 2001, "Competitive Biosorption of Phenol and Chromium (VI) from Binary Mixtures Onto Dried Anaerobic Activated Sludge," Biochemical Engineering Journal, Vol. 7, pp. 183193.

Aksu, Z. and Gonen, F., 2004, "Biosorption of Phenol by Immobilized Activated Sludge in a Continuous Packed Bed: Prediction of Breakthrough Curves," Process Biochemistry, Vol. 39, pp. 599-613.

Aksu, Z. and Yener, J., 2001, "A Comparative Adsorption / Biosorption Study of Mono-Chlorinated Phenols Onto Various Sorbents," Waste Management, Vol. 21, pp. 695-702.

Arica, M.Y., Bayramoglu, G., Yýlmaz, M., Bekta, S. and Genç, Ö., 2004, 'Biosorption of $\mathrm{Hg} 2+, \mathrm{Cd} 2+$, and Zn2+ by Ca-alginate and immobilized wood-rotting fungus FunaliaTtrogii," J. of Hazardous Materials, Vol. B109, pp. 191-199.

Denzili, A., Cihanger N., Rad, A.Y., Taner, M. and Alsancak G., 2004, "Removal of Chlorophenols from Synthetic Solutions Phanerochaete Chrysosporium," Process Biochemistry, Vol. 39, pp. 2025-2030.

Dubinin, M.M, 1960, "The Potential Theory of Adsorption of Gases and Vapors for Adsorbents with Energetically Non-Uniform Surface," Chem. Rev, Vol. 60, pp. 235-266.

Feng, D. and Aldrich C., 2004, "Adsorption of Heavy Metals by Biomaterials Derived from the Marine Alga Ecklonia Maxima," Hydrmetallurgy, Vol. 73, pp. 110.

Galiatsatou Polymnia, Metaxas Michail. and KasselouriRigopoulou Vasilia, 2002, Adsorption of Zinc by Activated Carbons Prepared from Solvent Extracted Olive Pulp," J. of Hazardous Materials, Vol. 91, pp. 187-203.

Gupta R., Ahuja P., Khan S. and Saxena, R.K., 2000, "Microbial Biosorbents: Meeting Challenges of Heavy Metal Pollution in Aqueous Solutions," Current Science, Vol. 78, pp. 967-973.

Ho, Y.S., 2004, "Pseudo-Isotherms Using a Second Order Kinetic Expression Constant Adsorption," Vol. 10, pp. 151-158.

Ho, Y.S., Chiang T.H. and Hsueh, Y.M., 2005, "Removal of Basic Dye from Aqueous Solution using Tree Fern as a Biosorbent," Process Biochemistry, Vol. 40, pp. 119-124.

Ho, Y.S., Porter, J.F. and McKay, G., 2002, "Equilibrium Isotherm Studies for the Sorption of Divalent Metal Ions onto Peat: Copper, Nickel, and Lead Single Component System," Water, Air, and Soil Pollution,
Vol. 141, pp. 1-33.

Ho, Y.S. and Mckay, G., 1999, "The Sorption of Lead (II) Ions on Peat," Water Research, Vol. 33, pp. 578-584.

Ibanez, J.P. and Umetsu Y., 2004, "Uptake of Trivalent Chromium from Aqueous Solutions using Protonated Dry Alginate Beads," Hydrometallurgy, Vol. 72, Vol. 327-334.

Juang, R.S., Wu, F.C. and Tseng, R.L., 1999, "Adsorption Removal of Copper (II) using Chitosan from Simulated Rinse Solutions Containing Chelating Agents," Water Research, Vol. 33, pp. 2403-2409.

Kongolo, K., Mwema, M.D., Banza, A.N. and Gock, E., 2003, "Cobalt and Zinc Recovery from Copper Sulphate Solution by Solvent Extraction," Minerals Engineering, Vol. 16, pp. 1371-1374.

Kurama, H. and Catalsarik, T., 2000, "Removal of Zinc Cyanide from a Leach Solution by an Anionic IonExchange Resin," Desalination, Vol. 129, pp. l-5.

Magdy, Y.H. and Daifullah, A.A.M., 1998, "Adsorption of a Basic Dye from Aqueous Solutions onto SugarIndustry-Mud in two Modes of Operations," Waste Management, Vol. 18, pp. 219-226.

Marquardt, D.W., 1963, "An Algorithm for Least-Squares Estimation of Non-Linear Parameters," J. Soc. (Ind.) Appl. Math, Vol. 11, pp. 431-441.

Martins, R., Pardo, R. and Boaventura, R., 2004, "Cadmium(II) and Zinc(II) Adsorption by the Aquatic Moss Fontinalis Antipyretica: Effect of Temperature, pH and Water Hardness," Water Research, Vol. 38, pp. 693-699.

McKay, G., Porter, J.F. and Prasad, G.R., 1999, "The Removal of Dye Colours from Aqueous Solutions by Adsorption on Low-Cost Materials," Water Air Soil Pollution, Vol. 114, pp. 423-438.

Mohan, D. and Singh K., 2002, "Single- and MultiComponent Adsorption of Cadmium and Zinc using Activated Carbon Derived from Bagasse - An Agricultural Waste," Water Research, Vol. 36, pp. 2304-2318.

Mohapatra, H. and Gupta, R., 2005, "Concurrent Sorption of $\mathrm{Zn}(\mathrm{II}), \mathrm{Cu}(\mathrm{II})$ and $\mathrm{Co}(\mathrm{II})$ by Oscillatoria Angustissima as a Function of $\mathrm{pH}$ in Binary and Ternary Metal Solutions," Bioresource Technology, Vol. 96, pp. 1387-1398.

Pagnanelli, F., Trifoni, M., Beolchini, F., Esposito, A., Toro, L. and Veglio, F., 2001, "Equilibrium Biosorption Studies in Single and Multi-Metal Systems," Process Biochemistry, Vol. 37, pp. 115124.

Pagnanellia Francesca., Mainellia Sara., Vegli Francesco. and Toroa Luigi., 2003, "Heavy Metal Removal by Olive Pomace: Biosorbent Characterization and Equilibrium Modelling," Chemical Engineering Science, Vol. 58, pp. 4709-4717

Peric, J., Trgo, M. and Medvidovic, V., 2004, "Removal of Zinc, Copper and Lead by Natural Zeolite - A Comparison of Adsorption Isotherms," Water Research, Vol. 38, pp. 1893-1899.

Preston, J.S. and du Preez, A.C., 2000, "Separation of 
Nickel and Calcium by Solvent Extraction using Mixtures of Carboxylic Acids and Alkylpyridines," Hydrometallurgy, Vol. 58, pp. 239-250.

Ramos Leyva., Jacome Bernal., Barron Mendoza., Rubio Fuentes. and Coronado Guerrero., 2002, "Adsorption of Zinc(II) from an Aqueous Solution Onto Activated Carbon," J. of Hazardous Materials, Vol. B90, pp. 2738.

Rao, J.R. and Viraraghavan, T., 2002, "Biosorption of Phenol from an Aqueous Solution by Aspergillus niger biomass," Bioresource Technology, Vol. 85, pp. 165-171.

Sheng, P.X., Ting, Y.P., Chen, J.P. and Hong, L., 2004, "Sorption of Lead, Copper, Cadmium, Zinc, and Nickel by Marine Algal Biomass: Characterization of Biosorptive Capacity and Investigation of Mechanisms," J. of Colloid and Interface Science, Vol. 27, pp. 131-141.
Srisuwan, G. and Thongchai, P., 2004, "Removal of Heavy Metals from Electroplating Wastewater by Membrane," Science Technology, Vol. 24, pp. 965976.

Strelko, V., Malik, D.J., Streat, M., 2002, "Characterization of the Surface of Oxidized Carbon Adsorbents, Carbon," Vol. 40, pp. 95-104.

Veeken, H.M., Akoto, L., Hulshoff, W. and Weijma, J., 2003, Control of the Sulfide (S-2) Concentration for Optimal Zinc removal by Sulfide Precipitation in a Continuously Stirred Tank Reactor," Water Research, Vol. 37, pp. 3709-3717.

Volesky, B., 2003, "Sorption and Biosorption. (ISBN 09732983-0-8)," BV Sorbex, Inc. Monterial - St. Lambert, Quebec, Canada.

Weber, W.J. and Morris J.C., 1963, "Kinetics of Adsorption on Carbon from Solution," J. Sanitary Engineering Division, American Society of Chemical Engineering, Vol. 89, pp. 31-59. 